\title{
Effect of Emblica officinalis Extract on Hepatocarcinogenesis and Carcinogen Metabolism
}

\author{
Jeena K. Jose, ${ }^{1}$ Ramadasan Kuttan, ${ }^{1, *}$ and Ratin Kumar Bhattachary ${ }^{2}$ \\ ${ }^{1}$ Amala Cancer Research Centre, Amala Nagar, \\ Thrissur 680 553, Kerala, India \\ ${ }^{2}$ Department of Radiation Biology and Biochemistry, Bhabha Atomic \\ Research Centre, Bombay 400 084, India
}

(Received March 2, 1998)

\begin{abstract}
Summary Emblica officinalis (E.O) extract was found to dose dependently lower the incidence of liver tumors induced by $N$-nitrosodiethylamine (NDEA). Control group rats (NDEA alone) had $100 \%$ tumor incidence, whereas in animals treated with E.O at a dose of $250 \mathrm{mg} / \mathrm{kg}$ body weight, the incidence was $0 \%$. The liver weight of the control group was $7.99 \pm 1.51 \mathrm{~g} / 100 \mathrm{~g}$ body weight, and that of the E.O-treated group showed a dose-dependent decrease (4.90-3.50 g/100 g body weight). NDEA treatment also increased serum and liver $\gamma$-glutamyl transpeptidase ( $\gamma$-GTP) activity to $135.5 \pm 27.9 \mathrm{U} /$ liter and $2.90 \pm 0.08 \mathrm{nmol} / \mathrm{min} /$ mg protein, respectively; and E.O treatment reduced these levels in a dose-dependent manner (99.8-44.8 U/ iter and $2.25-0.38 \mathrm{nmol} / \mathrm{min} / \mathrm{mg}$ protein). The level of liver aniline hydroxylase, a P-450 enzyme, was increased by the NDEA treatment, and this increase was reduced by the administration of the E.O extract. Liver glutathione- $S$-transferase (GST) activity, which was increased to $1,414 \pm 137 \mathrm{nmol} / \mathrm{min} / \mathrm{mg}$ protein by NDEA treatment, was found to be reduced in a dose-dependent manner by E.O in vivo. E.O extract was also found to inhibit aminopyrene- $N$ demethylase activity in vitro, with $301 \mu \mathrm{g} / \mathrm{ml}$ as the concentration needed for $50 \%$ inhibition. The extract was also found to inhibit DNA adduct formation induced by benzo $(a)$ pyrene $[\mathrm{B}(a) \mathrm{P}]$ and aflatoxin $\mathrm{B} 1$ (AFB1). The concentration of E.O extract required for $50 \%$ inhibition of microsome-catalyzed $\mathrm{B}(a) \mathrm{P}$ adduct formation was $280 \mu \mathrm{g} / \mathrm{ml}$; and that for AFB1 adduct formation, $120 \mu \mathrm{g} / \mathrm{ml}$. The results of the present study indicate that E.O extract can interfere with the metabolism of NDEA and inhibit liver tumor development by this carcinogen, suggesting its use in the prevention of hepatocarcinogenesis.
\end{abstract}

* To whom correspondence should be addressed. 
Key Words: Emblica officinalis, hepatocarcinogenesis, $N$-nitrosodiethylamine

Chemopreventive agents that are categorized under various chemical classes have been shown to inhibit tumor initiation, acting as blocking and suppressing agents [1]. Many environmental carcinogens needed activation mainly by P-450 enzymes to form their ultimate carcinogenic form that produces adducts with DNA and thereby mutations leading to the generation of cancer cells $[2,3]$. Oxygen radicals are associated with the activation of carcinogens as well as in the promotion of an initiated cell [4]. Scavengers of oxygen radicals have been shown to inhibit cancer development in animals and in human trials [5].

Emblica officinalis Gaertn. (E.O) is a well known plant used in many indigenous medical preparations $[6,7]$. It is non-toxic even at very high concentrations. We reported earlier that an extract of E.O had antioxidant activity and could scavenge superoxides and hydroxyl radicals, as well as inhibit lipid peroxidation [8]. We also showed that E.O could inhibit the mutagenicity produced by acetamidofluorene and could block the formation of methylcholanthrene-induced sarcoma in mice [9]. In the present study we examined the inhibition of $N$-nitrosodiethylamine-induced hepatocarcinogenesis by the E.O extract. We also explored the biological mechanism of action of the extract by estimating its effect on the inhibition of phase-1 and phase-II enzymes as well as its inhibition of carcinogen adduct formation.

\section{MATERIALS AND METHODS}

Aminopyrene, L-glutamyl-p-nitroanilide, glycyl glycine, and $N$-nitrosodiethylamine (NDEA) were purchased from Sigma Chemical Co. (St. Louis, MO). NADPH, 5,5'-dithiobis(2-nitrobenzoic acid) (DTNB), and reduced glutathione (GSH) were purchased from Sisco Research Laboratories, Bombay, India. 1Chloro-2,4-dinitrobenzene (CDNB) came from Loba Chemic Pvt. Ltd., Bombay, India. $\left[{ }^{3} \mathrm{H}\right.$ ] Aflatoxin $\mathrm{B} 1$ (AFB1) (specific radioactivity $11 \mathrm{Ci} / \mathrm{mmol}$ ) was purchased from Moravek Biochemicals Inc., Brea, CA. $\left[{ }^{3} \mathrm{H}\right] \operatorname{Benzo}(a)$ pyrene $[\mathrm{B}(a) \mathrm{P}]$ (specific radioactivity $5.3 \mathrm{Ci} / \mathrm{mmol}$ ) was supplied by the Board of Radiation and Isotope Technology, Mumbai, India. All other reagents used were of analytical reagent grade.

E.O fruits were purchased from a local market, and the extract was prepared by lyophilizing the supernatant of a $10 \%$ aqueous extract under vacuum.

Male Wistar rats were purchased from Veterinary College, Mannuthy, Kerala, India. They were housed in ventilated cages and fed a pellet diet (Lipton, India Ltd., Bangalone, India) and provided water ad libitum.

Determination of effect of E.O extract on inhibition of hepatocarcinogenesis. Six-week-old male Wistar rats weighing 120-150 g were divided into 5 groups 
(10 animals per group). Group I was kept as the normal control. Liver tumors were induced in groups II-V by oral administration of $0.02 \%$ NDEA in water 5 days per week for 20 weeks [10]. Group II served as the untreated control. E.O extract at doses of 50,125 , and $250 \mathrm{mg} / \mathrm{kg}$ body weight was administered orally to groups III, IV, and V, respectively. Administration of E.O extract was started 5 days prior to NDEA administration and continued throughout the 20 weeks. All of the animals were killed one week after the cessation of treatment. Blood and liver were taken for analysis. The change in liver weight and tumor incidence in each group were recorded. Serum $\gamma$-glutamyl transpeptidase $(\gamma$-GTP) was assayed with an AVT Kit (AVT Diagnostics, India Ltd., Cochin, India) based on a modification of Szasz's method [11]. Liver $\gamma$-GTP was assayed with $\gamma$-glutamyl- $p$-nitroanilide used as the substrate [12].

Inhibition of aniline hydroxylase activity. Aniline hydroxylase activity was measured with aniline employed as the substrate according to the method of Mazel [13]. The reaction mixture consisted of phosphate buffer $(0.5 \mathrm{ml}, 150 \mathrm{~mm}, \mathrm{pH} 7.4)$, $\mathrm{MgCl}_{2}(0.1 \mathrm{ml}, 75 \mathrm{~mm}), \mathrm{NADPH}(0.1 \mathrm{ml}, 5 \mathrm{~mm})$, aniline $(0.1 \mathrm{ml}, 120 \mathrm{~mm})$, and enzyme (1-1.5 mg protein) in a final volume of $1.5 \mathrm{ml}$. The assay mixture was incubated for $2 \mathrm{~h}$ at $37^{\circ} \mathrm{C}$, and $0.5 \mathrm{ml}$ of $20 \%$ TCA was then added to stop the reaction. The contents were mixed and centrifuged, and the supernatant was estimated for $p$-aminophenol. For this, $1 \mathrm{ml}$ of the TCA supernatant was mixed with $0.5 \mathrm{ml}$ of $10 \% \mathrm{Na}_{2} \mathrm{CO}_{3}$ solution and $1 \mathrm{ml}$ of $2 \%$ phenol in $0.2 \mathrm{~N} \mathrm{NaOH}$, and placed in an incubator at $37^{\circ} \mathrm{C}$ for $30 \mathrm{~min}$ for the development of color. The absorbance of blanks and samples were then read at $630 \mathrm{~nm}$.

Activity of cytosolic glutathione-S-transferase (GST) was determined by its ability to conjugate GSH with CDNB by the method of Habig et al. [14]. Tissue levels of GSH were determined by its reaction with DTNB by the method of Moron et al. [15].

Liver sections $(3-5 \mu \mathrm{m})$ were stained with hematoxylin-eosin and were examined $(10 \times)$ for histological examination.

Inhibition of aminopyrene- $N$-demethylase activity in vitro. Aminopyrene demethylase activity was assayed with aminopyrene as substrate according to the method of Mazel [13]. The reaction mixture consisted of phosphate buffer $(0.5 \mathrm{ml}$, $0.15 \mathrm{M}, \mathrm{pH} 7.4), \mathrm{MgCl}_{2}(0.1 \mathrm{ml}, 75 \mathrm{~mm})$, NADPH $(0.1 \mathrm{ml}, 5 \mathrm{~mm})$, aminopyrene $(0.1$ $\mathrm{ml}, 120 \mathrm{~mm})$, semicarbazide hydrochloride $(0.1 \mathrm{ml}, 120 \mathrm{mM})$, enzyme $(1-1.5 \mathrm{mg}$ protein) and different concentrations $(0.1-0.75 \mathrm{mg})$ of E.O extract in a final volume of $1.5 \mathrm{ml}$. The assay mixture was incubated at $37^{\circ} \mathrm{C}$ for $2 \mathrm{~h}$. The reaction was then stopped by the addition of $0.5 \mathrm{ml}$ of $10 \% \mathrm{ZnSO}_{4}$ and $0.5 \mathrm{ml}$ of a saturated solution of $\mathrm{Ba}(\mathrm{OH})_{2}$, and the contents were centrifuged. The supernatant was taken for estimation of formaldehyde by condensation with Nash reagent. For this, $1 \mathrm{ml}$ of the supernatant was treated with $0.5 \mathrm{ml}$ of the Nash reagent. The tubes were placed in a water bath at $60^{\circ} \mathrm{C}$ for $30 \mathrm{~min}$ for color development, and the absorbance was measured at $412 \mathrm{~nm}$.

Determination of DNA adduct formation. The labeled carcinogens were Vol. 25, No. 1, 1998 
diluted with unlabeled samples dissolved in DMSO to give the desired concentrations. Liver microsomes were isolated from male Wistar rats of $150 \mathrm{~g}$ given Aroclor 1254 or phenobarbital [16]. The $\mathrm{B}(a) \mathrm{P}-\mathrm{DNA}$ adduct formation was carried out by reacting the DNA $(0.5 \mathrm{mg})$ with $20 \mu \mathrm{Ci}$ of $\left[{ }^{3} \mathrm{H}\right] \mathrm{B}(a) \mathrm{P}$ (specific radioactivity 333 $\mu \mathrm{Ci} / \mu \mathrm{mol}, 60 \mu \mathrm{M}$ final conc.) in a $1-\mathrm{ml}$ reaction mixture containing $15 \mathrm{~mm}$ sodium phosphate buffer ( $\mathrm{pH} 7.4$ ), $25 \mathrm{~mm}$ EDTA ( $\mathrm{pH} 7.2$ ), $0.65 \mathrm{~mm} \mathrm{NADPH}$, and $0.5 \mathrm{mg}$ of microsomal protein. After incubation at $37^{\circ} \mathrm{C}$ for $30 \mathrm{~min}$, the reaction was stopped by addition of $1 \mathrm{ml}$ of chilled $15 \mathrm{~mm}$ phosphate buffer, and DNA was extracted, estimated, and counted for radioactivity as described earlier [17]. Microsome-mediated binding of $\left[{ }^{3} \mathrm{H}\right] \mathrm{AFB} 1$ to DNA was carried out following a previously established procedure [18]. Briefly, DNA $(0.5 \mathrm{mg})$ was reacted with 0.5 $\mu \mathrm{Ci}$ of $\left[{ }^{3} \mathrm{H}\right] \mathrm{AFB} 1$ (specific radioactivity $250 \mu \mathrm{Ci} / \mu$ mol, $2 \mu \mathrm{M}$ final conc.) in $1 \mathrm{ml}$ of potassium phosphate buffer ( $\mathrm{pH} 7.4$ ) containing $5 \mathrm{mM} \mathrm{Mg}^{2+}, 0.65 \mathrm{~mm} \mathrm{NADPH}$, and $0.35 \mathrm{mg}$ of microsomal protein. Following incubation at $37^{\circ} \mathrm{C}$ for $60 \mathrm{~min}$, the DNA was processed for estimation and counting. E.O extract freshly dissolved in DMSO was added to the above reaction mixture of DNA adduct formation at the desired concentration before the addition of microsomes. Solvent concentration was kept at $1 \%(\mathrm{v} / \mathrm{v})$, and a control was included with each assay conducted in duplicate.

\section{RESULTS}

\section{Inhibition of hepatocarcinogenesis by E.O extract}

E.O extract was found to inhibit hepatocarcinogenesis induced by NDEA significantly (Table 1). Control animals developed frank hepatomas after about 18-20 weeks of carcinogen feeding. The incidence of liver tumors in the group treated with NDEA alone was 100\%. Administration of E.O extract at doses of 125 $\mathrm{mg}$ and $50 \mathrm{mg} / \mathrm{kg}$ body weight reduced the liver tumor incidence to 60 and $30 \%$,

Table 1. Effect of E.O extract on NDEA-induced hepatocarcinogenesis in male Wistar rats.

\begin{tabular}{|c|c|c|c|c|c|c|}
\hline \multirow[b]{2}{*}{ Group } & \multirow[b]{2}{*}{$\begin{array}{c}\text { No. of } \\
\text { animals }\end{array}$} & \multirow{2}{*}{$\begin{array}{l}\text { No. of } \\
\text { tumor- } \\
\text { bearing } \\
\text { animals }\end{array}$} & \multirow[b]{2}{*}{$\begin{array}{l}\% \text { tumor } \\
\text { incidence }\end{array}$} & \multirow{2}{*}{$\begin{array}{c}\text { Liver } \\
\text { weight g/ } \\
100 \mathrm{~g} \mathrm{body} \\
\text { weight }\end{array}$} & \multicolumn{2}{|c|}{$\gamma$-GTP } \\
\hline & & & & & $\begin{array}{c}\text { Serum } \\
\text { (U/liter) }\end{array}$ & $\begin{array}{c}\text { Liver (nmol/ } \\
\text { min/mg } \\
\text { protein) }\end{array}$ \\
\hline Normal & 10 & 0 & 0 & $3.01 \pm 0.88$ & $34.3 \pm 2.0$ & $0.08 \pm 0.02$ \\
\hline $\begin{array}{l}\text { Control } \\
\text { (NDEA alone) }\end{array}$ & 10 & 10 & 100 & $7.99 \pm 1.51$ & $135.5 \pm 27.9$ & $2.90 \pm 0.08$ \\
\hline E.O $(50 \mathrm{mg})$ & 10 & 6 & 60 & $4.90 \pm 0.74^{* *}$ & $99.8 \pm 4.9$ & $2.25 \pm 0.05$ \\
\hline E.O (125 mg) & 10 & 3 & 30 & $4.13 \pm 0.60^{* * *}$ & $80.4 \pm 6.6^{*}$ & $1.85 \pm 0.28^{* * *}$ \\
\hline E.O $(250 \mathrm{mg})$ & 10 & 0 & 0 & $3.50 \pm 0.45^{* * *}$ & $44.8 \pm 7.8^{* * *}$ & $0.38 \pm 0.10^{* * *}$ \\
\hline
\end{tabular}


respectively, whereas there were no tumors in the group treated with $250 \mathrm{mg}$ E.O extract (group V). The average liver weight in the control group was $7.99 \pm 1.51 \mathrm{~g} /$ $100 \mathrm{~g}$ body weight. E.O-treated groups showed decreased enlargement of the liver in a dose-dependent manner (4.9-3.5 g/100 g body weight). Serum and liver $\gamma$ GTP activities were found to be significantly reduced by the administration of E.O extract. The level of normal serum $\gamma$-GTP was $34.28 \pm 2.0 \mathrm{U} /$ liter, and this was increased to $135.5 \pm 27.9 \mathrm{U} /$ liter in the case of control animals treated with NDEA only. E.O-treated group had a lower serum $\gamma$-GTP level, which was lowered dose dependently (99.8-44.8 U/liter). This was also reflected in the liver $\gamma$-GTP profile.

The NDEA-treated group showed increased aniline hydroxylase activity $(0.47 \pm 0.06 \mu \mathrm{mol} / \mathrm{min} / \mathrm{mg}$ protein $)$ compared with the normal level $(0.21 \pm 0.18)$. Administration of E.O extract decreased the activity in a dose-dependent manner (from $0.412 \pm 0.03$ to $0.29 \pm 0.02 \mu \mathrm{mol} / \mathrm{min} / \mathrm{mg}$ protein) (Table 2).

The GST level of NDEA-treated animals was higher $(1,414 \pm 137 \mathrm{nmol} / \mathrm{min} /$ mg protein) as compared with that of normal ones $(588 \pm 55)$. A dose-dependent decrease in this level (from $886 \pm 29$ to $532 \pm 18 \mathrm{nmol} / \mathrm{min} / \mathrm{mg}$ protein) was observed for the E.O-treated group. The GSH level of the NDEA-treated group was $20.4 \pm 1.3 \mathrm{nmol} / \mathrm{mg}$ protein. The E.O extract at the concentrations used had only a marginal effect on the GSH concentration.

Morphological picture of rat liver treated with NDEA with and without E.O treatment are given in Fig. 1A and B. The size and weight of the NDEA-treated liver were significantly higher than those of the liver from E.O-treated rats. In the latter case the size was almost similar to normal.

Histopathological analysis of the liver indicated that it to be hepatic adenocarcinoma and of cystic type. Malignant cells seen as infiltrating cords and shows degenerative changes and necrosis. These changes were minimal in E.O-treated tissues, and the normal architecture of the liver was preserved (Fig. 2A and B).

\section{Effect of E.O extract on aminopyrene demethylase activity in vitro}

The E.O extract was found to inhibit the activity of aminopyrene demethylase

Table 2. Effect of E.O extract on carcinogen-metabolizing enzymes and glutathione levels in liver.

\begin{tabular}{lccc}
\hline Group & $\begin{array}{c}\text { Aniline hydroxylase } \\
(\mu \mathrm{mol} / \mathrm{min} / \mathrm{mg} \\
\text { protein })\end{array}$ & $\begin{array}{c}\text { GST } \\
(\mathrm{nmol} / \mathrm{min} / \mathrm{mg} \\
\text { protein })\end{array}$ & $\begin{array}{c}\text { GSH } \\
(\mathrm{nmol} / \mathrm{mg} \text { protein })\end{array}$ \\
\hline Normal & $0.21 \pm 0.18$ & $588 \pm 55$ & $8.9 \pm 0.1$ \\
Control (NDEA alone) & $0.47 \pm 0.06$ & $1,414 \pm 137$ & $20.4 \pm 1.3$ \\
NDEA + E.O (50 mg) & $0.41 \pm 0.03$ & $886 \pm 29^{* *}$ & $20.3 \pm 1.4$ \\
NDEA + E.O (125 mg) & $0.35 \pm 0.05^{*}$ & $648 \pm 21^{* *}$ & $17.5 \pm 1.6$ \\
NDEA + E.O (250 mg) & $0.29 \pm 0.02^{* *}$ & $532 \pm 18^{* *}$ & $15.2 \pm 0.5^{* *}$ \\
\hline
\end{tabular}

${ }^{*} p<0.02,{ }^{* *} p<0.001$. Animals were treated with $0.02 \%$ NDEA in water 5 days per week for 20 weeks. Different concentrations of E.O extract $(50-250 \mathrm{mg} / \mathrm{kg}$ body weight) were administered orally, and the parameters were assayed as given in Materials and Methods. 
in vitro, which is a microsomal P-450 enzyme and implicated in the activation of carcinogens. Inhibition was found to be dose dependent (Fig. 3). The concentration required for $50 \%$ inhibition was $301 \mu \mathrm{g} / \mathrm{ml}$.

\section{Effect of E.O extract on DNA adduct formation}

Microsome-catalyzed $\mathrm{B}(a) \mathrm{P}$ and AFB1 adduct formation in the presence of E.O extract are shown in Fig. 4. The E.O extract inhibited the DNA adducts formed by $\mathrm{AFB} 1$ and $\mathrm{B}(a) \mathrm{P}$ significantly in a concentration-dependent manner. The $\mathrm{IC}_{50}$ with $\mathrm{B}(a) \mathrm{P}$ was $280 \mu \mathrm{g} /$ plate, and that with AFB1 was $120 \mu \mathrm{g} / \mathrm{plate}$. At higher concentrations the adduct formation was inhibited more than $74 \%$ by $\mathrm{B}(a) \mathrm{P}$ and $90 \%$ by AFB1.

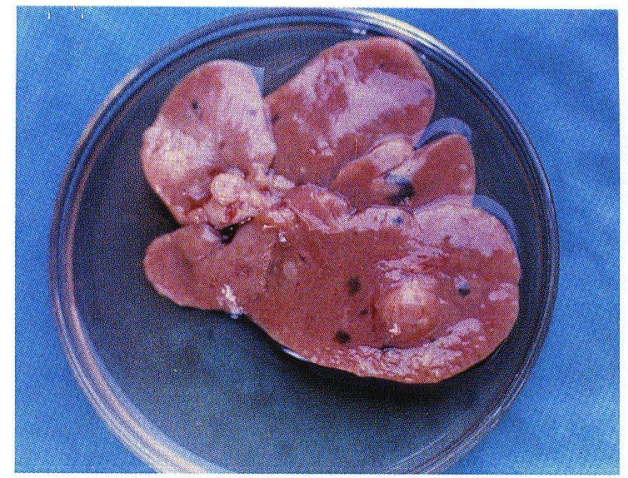

(A)

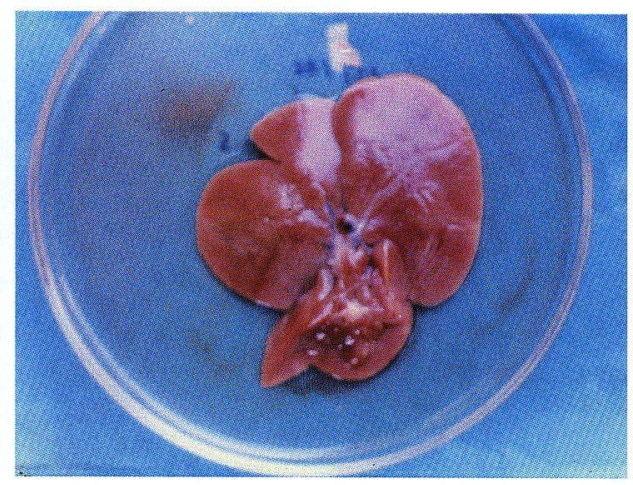

(B)

Fig. 1. Morphology of rat liver treated with NDEA. A, NDEA alone: B, NDEA+E.O ( $250 \mathrm{mg} / \mathrm{kg}$ body weight).

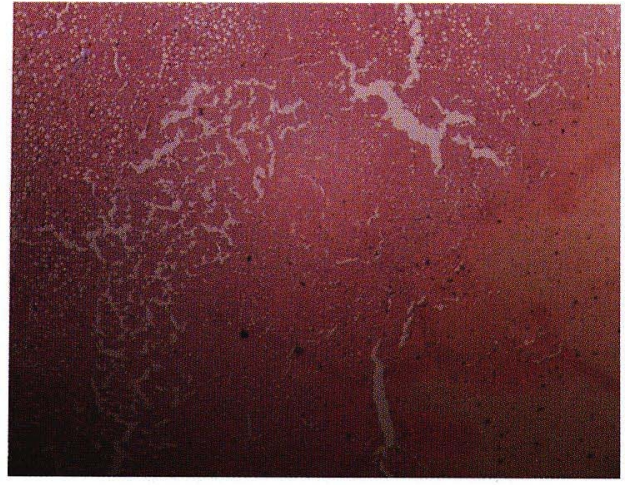

(A)

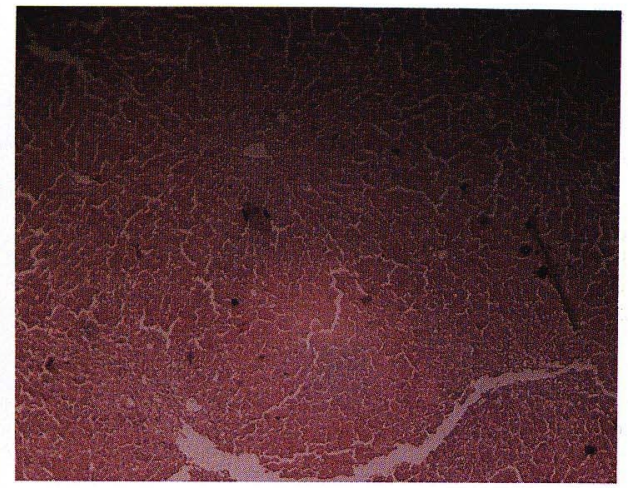

(B)

Fig. 2. Histopathology of rat liver treated with NDEA. A, NDEA alone; B, NDEA+E.O $(250 \mathrm{mg} / \mathrm{kg}$ body weight). 


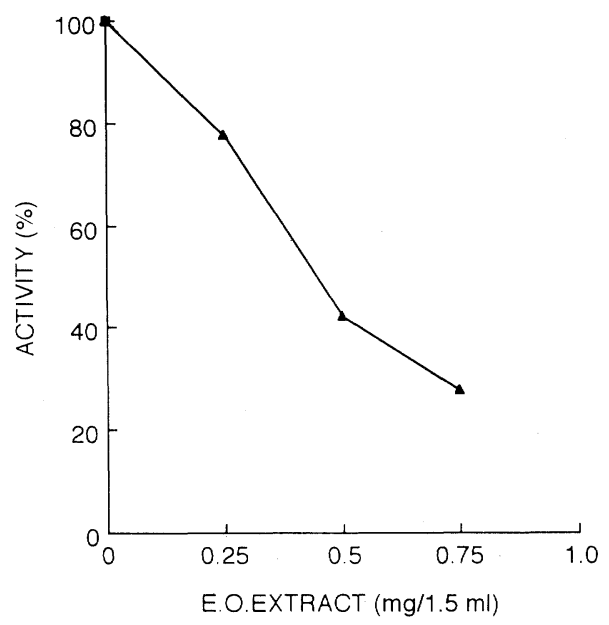

Fig. 3. Effect of E.O extract on aminopyrene-N-demethylase activity in vitro.

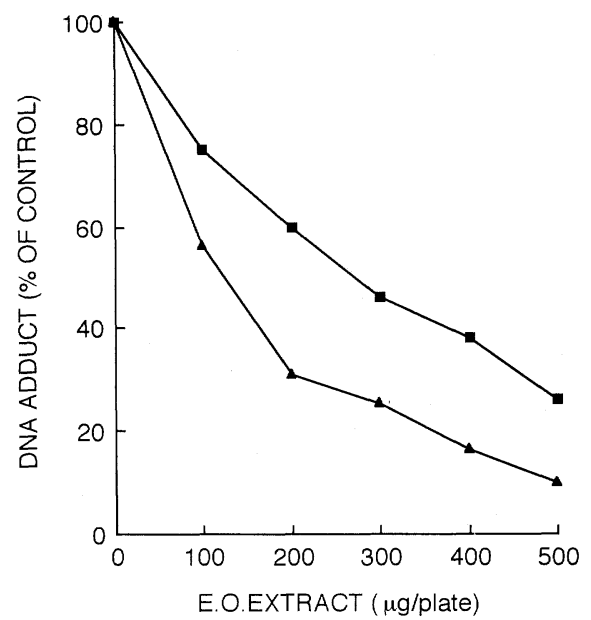

Fig. 4. Effect of E.O extract on microsome-catalyzed carcinogen-DNA adduct formation.

๘, $\mathrm{B}(a) \mathrm{P} ; \mathbf{\Lambda}, \mathrm{AFB} 1$.

\section{DISCUSSION}

The damage to DNA caused by the binding of reactive metabolites, which are generated by biotransformation of carcinogenic compounds, is one of the important mechanisms underlying carcinogenic activity [19]. Many chemical carcinogens such as $\mathrm{B}(a) \mathrm{P}$, aflatoxin, and nitrosoamines have been shown to undergo cyt. $\mathrm{P}-450$-dependent activation to form the ultimate reactive species. Compounds that Vol. 25, No. 1, 1998 
can inhibit this initiation step will be highly useful in chemoprevention strategies.

We reported earlier that an aqueous extract of E.O was a potent antioxidant, and the results of the present study indicate that apart from its antioxidant activity E.O extract also inhibited phase-1 enzymes such as aniline hydroxylase [9] and aminopyrene- $N$-demethylase in vitro. NDEA treatment increased aniline hydroxylase and GST levels significantly, and the E.O extract could block these increases in a dose-dependent manner. Moreover, the extract could inhibit DNA adduct formation, which is a pre-requisite for the carcinogen-induced mutagenesis and malignant formation. The present experiment also indicates that oral administration of E.O extract could reduce the hepatocarcinogenesis induced by NDEA significantly. Interference with metabolic activation of NDEA through inhibition of the mixed function oxidase system and DNA adduct formation at early stages of NDEA treatment by the E.O extract may be one of the important factor associated with the suppression of NDEA-induced hepatocarcinogenesis.

One of the desired qualities of a chemopreventive agent is its non-toxicity. E.O extract was found to be non-toxic at very high concentrations $(>1.25 \mathrm{~g} / \mathrm{kg}$ body weight). It is also used in many dietary preparations as well as is an important ingredient in indigenous medical preparations. Hence this may be an ideal material for chemopreventive trials.

The active ingredient responsible for the activity is not completely understood. E.O has been reported to contain tannins, trigalloyl glucose, flavonoids, and several polyphenolic compounds including ellagic acid and phyllemblic acid [8]. Ghosal et al. reported the presence of antioxidative, hydrolyzable tannins Emblicanin A, Emblicanin B, punigluconin, and pedunculagin in E.O [20]. These polyphenolic compounds as well as their glycosides may be responsible for the antioxidant and anticarcinogenic activity of E.O. Although E.O has been reported to contain ascorbic acid [21], our initial results on the nature of the active material indicates that ascorbic acid has only a minor role in the biological activity of E.O. This is further substantiated by a recent work that questions the presence of ascorbic acid in E.O fruit [20].

This work was supported by a grant from the Council of Scientific and Industrial Research.

\section{REFERENCES}

1. Wattenberg, L.W. (1985): Chemoprevention of cancer. Cancer Res., 45, 1-8.

2. Essigman, J.M., Croy, R.G., Bennet, R.A., and Wogan, G.N. (1982): Metabolic activation of aflatoxin B1: Patterns of DNA-adduct formation, removal and excretion in relation to carcinogenesis. Drug Metab. Rev., 13, 581-602.

3. Burgess, J.A., Stevens, C.W., and Fahl, W.E. (1985): Mutation at separate gene loci in Salmonella typhymurium TA 100 related to DNA molecule. Cancer Res., 45, 4257-4262.

4. Cerutti, P.A. (1985): Pro-oxidant states and tumor promotion. Science, 227, 375-381.

5. Sun, Y. (1990): Free radicals, antioxidant enzymes and carcinogenesis. Free Radic. Biol. Med., 8, 583-599.

6. Thakur, C.P., Thakur, B., Sinha, P.K., and Sinha, S.K. (1988): The Aurvedic medicines 
Haritaki, Amlaki and Bahira reduce cholesterol-induced atherosclerosis in rabbits. Int. J. Cardiol., 21, 167-175.

7. De, S., Ravishankar, B., and Bhavsar, G.C. (1993): Plants with hepatoprotective activity-A review. Indian Drugs, 30, 355-363.

8. Jose, J.K., and Kuttan, R. (1995): Antioxidant activity of Emblica officinalis. J. Clin. Biochem. Nutr., 19, 63-70.

9. Jose, J.K., Kuttan, G., George, J., and Kuttan, R. (1997): Antimutagenic and anticarcinogenic activity of Emblica officinalis Gaertn. J. Clin. Biochem. Nutr., 22, 171-176.

10. Narurkar, L.M., and Narurkar, M.V. (1989): Role of nicotinamide in suppression of diethylnitrosamine hepatocarcinogenesis in rats, in Chemoprevention of Cancer, ed. by Bhide, S.V., and Maru, G.B., Omega Scientific Publishers, New Delhi, pp. 162-177.

11. Szasz, G. (1976): Reaction rate method for $\gamma$-glutamyl transferase activity in serum. Clin. Chem., 22, 2031-2055.

12. Tate, S.S., and Meister, A. (1974): Interaction of $\gamma$-glutamyl transpeptidase with amino acids, peptides, and derivatives and analogues of glutathione. J. Biol. Chem., 23, 7593-7602.

13. Mazel, P. (1971): Experiments illustrating drug metabolism in vitro, in Fundamentals of Drug Metabolism and Drug Disposition, ed. by LaDu, B.N., Mandel, H.G., and Way, E.L., Williams and Wilkins, Baltimore, pp. 546-578.

14. Habig, W.H., Pabst, M.J., and Jakoby, W.R. (1974): Glutathione-S-transferase. The first enzymatic step in mercapturic acid formation. J. Biol. Chem., 249, 7130-7139.

15. Moron, M.A., DePierre, J.W., and Mannervick, B. (1979): Levels of glutathione, glutathione reductase, and glutathione-S-transferase activities in rat liver. Biochim. Biophys. Acta, 582, 67-78.

16. Shah, G.M., and Bhattacharya, R.K. (1982): In vivo effect of L-ascorbic acid on benzo(a)pyrene metabolite-DNA adduct formation in rat liver. J. Biosci., 4, 263-268.

17. Shah, G.M., and Bhattacharya, R.K. (1986): Modulation by plant flavonoids and related phenolics of microsome catalysed adduct formation between $\mathrm{B}(a) \mathrm{P}$ and DNA. Chem. Biol. Interact., 59, 1-5.

18. Bhattacharya, R.K., Firozi, P.F., and Aboobaker, V.S. (1984): Factors modulating the formation of DNA adduct by aflatoxin B1 in vitro. Carcinogenesis, 5, 1359-1362.

19. Conney, A.H. (1982): Induction of microsomal enzymes by foreign chemicals and carcinogenesis by polycyclic hydrocarbons. Cancer Res., 42, 4875-4917.

20. Ghosal, S., Tripathi, V.K., and Satish, C. (1996): Active constituents of Emblica officinalis: Part 1. The chemistry and antioxidative effects of two new hydrolysable tannins, Emblicanin A and B. Indian J. Chem., 35, 941-948.

21. Brahmachari, H.D., and Gupta, V.S. (1958): Studies on Phyllanthus emblica (Amla): Part III. Role of tannins in stabilizing the ascorbic acid of the fruit. Indian J. Appl. Chem., 21, 173-174. 